\title{
Molecular diagnostics, field validation, and phylogenetic analysis of Quahog Parasite Unknown (QPX), a pathogen of the hard clam Mercenaria mercenaria
}

\author{
N. A. Stokes*, L. M. Ragone Calvo, K. S. Reece, E. M. Burreson \\ School of Marine Science, Virginia Institute of Marine Science, College of William and Mary, Gloucester Point, \\ Virginia 23062, USA
}

\begin{abstract}
Quahog Parasite Unknown (QPX) is a protistan parasite that causes disease and mortality in the hard clam Mercenaria mercenaria. PCR primers and DNA oligonucleotide probes were designed and evaluated for sensitivity and specificity for the QPX organism specifically and for the phylum Labyrinthulomycota in general. The best performing QPX-specific primer pair amplified a $665 \mathrm{bp}$ region of the QPX small-subunit ribosomal DNA (SSU rDNA) and detected as little as $1 \mathrm{fg}$ cloned QPX SSU rDNA and $20 \mathrm{fg}$ QPX genomic DNA. The primers did not amplify DNA of uninfected hard clams $M$. mercenaria or of the thraustochytrids Schizochytrium aggregatum, Thraustochytrium aureum, and T. striatum. The general labyrinthulomycete primers, which were designed to offer broader specificity than the QPX primers, amplified a 435 bp region of SSU rDNA from QPX, and a 436 to $437 \mathrm{bp}$ region of SSU rDNA from $S$. aggregatum, T. aureum, and $T$. striatum, but did not amplify that of the clam $M$. mercenaria. Field validation of the QPX-specific primer pair, through comparative sampling of 224 clams collected over a 16 mo period from a QPX endemic site in Virginia, USA, indicated that the PCR assay is equivalent to histological diagnosis if initially negative PCR products are reamplified. Oligonucleotide DNA probes specific for QPX and the phylum Labyrinthulomycota were evaluated for in situ hybridization assays of cell smears or paraffinembedded tissues. Two DNA probes for QPX offered limited sensitivity when used independently; however, when used together as a probe cocktail, sensitivity was greatly enhanced. The probe cocktail hybridized to putative QPX organisms in tissues of hard clams collected from Virginia, New Jersey, Massachusetts and Canada, suggesting that the QPX organisms in these areas are either very closely related or the same species. The QPX probe cocktail did not hybridize with clam tissue or with the thraustochytrids $S$. aggregatum, T. aureum, and T. striatum. The labyrinthulomycete DNA probe hybridized with QPX and the 3 thraustochytrids, with no background hybridization to clam tissue. SSU rDNA sequences were obtained for the putative QPX organisms from geographically distinct sites. Phylogenetic analyses based on the QPX and Labyrinthulomycota sequences confirmed earlier reports that QPX is a member of this phylum, but could not definitively demonstrate that all of the QPX organisms were the same species.
\end{abstract}

KEY WORDS: Hard clams $\cdot$ Disease $\cdot$ QPX $\cdot$ Molecular techniques $\cdot$ PCR $\cdot$ Probe Resale or republication not permitted without written consent of the publisher

\section{INTRODUCTION}

QPX (Quahog Parasite Unknown) causes a disease of hard clams that has been documented to be present

*Email: stokes@vims.edu in New Brunswick, Nova Scotia, and Prince Edward Island, Canada, and at various locations in Massachusetts, New Jersey, and Virginia, USA (Drinnan \& Henderson 1963, Whyte et al. 1994, Ragone Calvo et al. 1998, Smolowitz et al. 1998, MacCallum \& McGladdery 2000). The pathogen has been most problematic in populations of cultured hard clams. Although first

(C) Inter-Research $2002 \cdot$ www.int-res.com 
observed in the late 1950s in New Brunswick, Canada, where it caused high mortalities of wild hard clams (Drinnan \& Henderson 1963), it did not become a recognized threat to hard clam aquaculture until the late 1980s and early 1990s. Morphological and molecular evidence suggests that the organism is a member of the phylum Labyrinthulomycota (Whyte et al. 1994, Smolowitz et al. 1998, Maas et al. 1999, Ragan et al. 2000). Members of this phylum are most commonly associated with sediments, vascular plants, benthic algae and detritus in marine and estuarine environments (Porter 1989). A few parasitic species have been identified within this group (McLean \& Porter 1982, Jones \& O'Dor 1983, Bower 1987).

Based on our present understanding, QPX is an opportunistic facultative parasite that is widespread in high salinity coastal environments. QPX-associated mortalities have been limited to market and nearmarket sized clams; the pathogen has not been detected in hatchery-produced seed clams (Ford et al. 1997). Outbreaks of QPX disease can be sudden and catastrophic; hard clam crop losses exceeding $80 \%$ have been documented in Massachusetts, New Jersey and Virginia (Smolowitz et al. 1998, Ragone Calvo unpubl. data).

The swiftness by which epizootics can emerge, and their potentially devastating impact, necessitates the development of effective disease management strategies for both traditional fisheries and aquaculture. This requires both an understanding of the epizootiology of a particular disease and the ability to perform rapid, sensitive, and accurate diagnosis of disease agents. In recent years DNA-based techniques have enhanced our ability to diagnose marine bivalve diseases and provided a suite of new tools for conducting novel research. The objectives of this study were: (1) to develop sensitive and specific molecular tools, PCR primers and a DNA probe, for the diagnosis of QPX in hard clams; (2) to field validate the PCR QPX diagnostic assay relative to standard histological diagnostic methods; and (3) to utilize the molecular tools to determine the relationship of geographically distinct putative QPX organisms from the United States and Canada.

\section{MATERIALS AND METHODS}

Isolation and sequencing of QPX small-subunit ribosomal DNA. In vitro cultures of QPX were obtained from Dr. Roxanna Smolowitz (Marine Biological Laboratory, Woods Hole, MA). The cultures were established from QPX cells that were isolated from infected hard clams from Duxbury, Massachusetts, as described by Kleinschuster et al. (1998). QPX genomic
DNA was extracted from an aliquot of the culture as previously described for Perkinsus marinus cultured cells (Reece et al. 1997). The small subunit ribosomal DNA (SSU rDNA) was amplified by PCR from the QPX genomic DNA using universal SSU primers for eukaryotic organisms (Medlin et al. 1988). PCR reaction mixtures contained reaction buffer (10 mM Tris, $\mathrm{pH} 8.3$; $50 \mathrm{mM} \mathrm{KCl}_{i} 1.5 \mathrm{mM} \mathrm{MgCl}_{2} ; 10 \mu \mathrm{g} \mathrm{ml}^{-1}$ gelatin), $400 \mu \mathrm{g}$ $\mathrm{ml}^{-1}$ bovine serum albumin, 25 pmol of each primer, $200 \mu \mathrm{M}$ each of dATP, dCTP, dGTP, dTTP, 0.6 units AmpliTaq DNA polymerase (Perkin-Elmer), and template DNA, to a total volume of $25 \mu$ l. The reaction mixtures were cycled in a GeneAmp PCR System 9600 thermal cycler (Perkin-Elmer) 35 times at $94^{\circ} \mathrm{C}$ for $30 \mathrm{~s}$, $45^{\circ} \mathrm{C}$ for $30 \mathrm{~s}$, and $65^{\circ} \mathrm{C}$ for $2 \mathrm{~min}$, with a final extension at $65^{\circ} \mathrm{C}$ for $5 \mathrm{~min}$.

PCR products from 3 separate reactions were pooled, purified by spin column (PCR Select III, 5 Prime-3 Prime), ligated into the plasmid vector pCR2.1 (Invitrogen), and transformed into Escherichia coli INV $\alpha F^{\prime}$ cells. Plasmid DNA was prepared from clones containing inserts using the Perfect Prep kit (5 Prime-3 Prime). These were cycle sequenced via simultaneous bidirectional sequencing using M13 forward and reverse primers labeled with the fluorescent dyes IRD-700 and IRD-800 (LI-COR). Sequencing reactions were electrophoresed on $66 \mathrm{~cm} 4 \%$ polyacrylamide gels in a LICOR Model 4200 automated sequencer. A consensus sequence for nearly full-length QPX SSU rDNA was obtained from 12 separate clonal sequences using the MacVector 7.0 DNA sequence analysis software package (Oxford Molecular) and deposited into GenBank (accession no. AY052644).

Primer and probe development. The QPX SSU rDNA sequence was aligned with SSU rDNA sequences downloaded from GenBank for hard clam Mercenaria mercenaria (accession no. AF106073) and members of the phylum Labyrinthulomycota. Sequences for the latter available at the time were: Aplanochytrium kerguelense (AB022103), Japonochytrium sp. (AB022104), Labyrinthula sp. (AB022105), Labyrinthuloides haliotidis (U21338), L. minuta (L27634), Schizochytrium aggregatum (AB022106), S. limacinum (AB022107), S. minutum (AB022108), Thraustochytrium aggregatum (AB022109), T. aureum (AB022110), T. kinnei (L34668), T. multirudimentale (AB022111), T. pachydermum (AB022113), T. striatum (AB022112), Ulkenia profunda (L34054, AB022114), U. radiata (AB022115), and $U$. visurgensis (AB022116). Regions that appeared to be specific for either QPX or the labyrinthulomycetes in general were identified. Sequences appropriate for use as PCR primers and/or DNA probes were checked for specificity and applicability by BLAST analysis (Altschul et al. 1997) and MacVector software. Probe and primer candidates 
were commercially synthesized (Genosys Biotechnologies); DNA probes were 5' end-labeled with digoxigenin.

Evaluation of primer sensitivity and specificity. Sequences of QPX and labyrinthulomycete PCR primers are listed in Table 1. Initial PCR reactions were conducted with plasmid QPX SSU rDNA to optimize amplification conditions (i.e. annealing temperature, $\mathrm{MgCl}_{2}$ concentration). All candidate primers were then tested for specificity to determine the best primer pairs. Primer pairs QPX-F + QPX-R2 and LABY-A + QPX-R2 were tested for QPX specificity and LABY-A + LABY-Y were tested for labyrinthulomycete specificity. PCR reaction mixtures for QPX-F + QPX-R2 and for LABY$\mathrm{A}+\mathrm{QPX}-\mathrm{R} 2$ contained reaction buffer $(60 \mathrm{mM}$ Tris, $\mathrm{pH}$ $\left.8.5 ; 15 \mathrm{mM}\left[\mathrm{NH}_{4}\right]_{2} \mathrm{SO}_{4} ; 3.5 \mathrm{mM} \mathrm{MgCl} 2\right), 400 \mu \mathrm{g} \mathrm{ml}{ }^{-1}$ bovine serum albumin, $25 \mathrm{pmol}$ of each primer, $200 \mu \mathrm{M}$ each of dATP, dCTP, dGTP, dTTP, 0.6 units AmpliTaq DNA polymerase (Perkin-Elmer), and template DNA, to a total volume of $25 \mu \mathrm{l}$. PCR reaction mixtures for LABY-A + LABY-Y were identical except that the reaction buffer contained $2 \mathrm{mM} \mathrm{MgCl}_{2}$. The QPX-F + QPXR2 reaction mixtures were cycled in a GeneAmp PCR System 9600 thermal cycler (Perkin-Elmer) 35 times at $94^{\circ} \mathrm{C}$ for $30 \mathrm{~s}, 56^{\circ} \mathrm{C}$ for $30 \mathrm{~s}$, and $72^{\circ} \mathrm{C}$ for $1.5 \mathrm{~min}$, with a final extension at $72^{\circ} \mathrm{C}$ for $5 \mathrm{~min}$. The LABY-A + QPX-R2 and LABY-A + LABY-Y reaction mixtures had identical cycling conditions except that the annealing temperature was $50^{\circ} \mathrm{C}$. An aliquot of each reaction (10\% of reaction volume) was checked by agarose gel electrophoresis for the expected product sizes of 665 bp for QPX-F + QPX-R2, ca. 435 bp for LABY-A + LABY-Y, and $396 \mathrm{bp}$ for LABY-A + QPX-R2 reactions.

Specificity of the PCR assays was determined using SSU rDNA plasmids for QPX and clam, and genomic DNA of cultured QPX cells, QPX-infected and uninfected clams (diagnosed by histological examination), and the thraustochytrids Schizochytrium aggregatum (ATCC 28209), Thraustochytrium aureum (ATCC 34304), and T. striatum (ATCC 24473). Thraustochytrids were chosen for specificity testing since previous work showed that QPX is morphologically and phylogenetically closest to this group (Whyte et al. 1994, Smolowitz et al. 1998, Maas et al. 1999, Ragan et al. 2000). QPX-infected and uninfected clams were collected from Burton Bay and Black Narrows, Chincoteague Bay, Virginia, in spring 1997 and 1998. Clams were considered uninfected when no QPX cells were detected by histological examination of the tissue section. Clam SSU rDNA plasmids were prepared as described above for QPX. Total genomic clam DNA was isolated from approximately $150 \mathrm{mg}$ mantle tissue of the clam samples by guanidine thiocyanate lysis (GTC) (Yarnall et al. 2000). Cultured cells of the 3 thraustochytrids were purchased from ATCC (Manasses, VA) and maintained in ATCC culture medium 790 (1 g yeast extract, $1 \mathrm{~g}$ peptone, $5 \mathrm{~g} \mathrm{D}+$-glucose in $1 \mathrm{l}$ seawater). Cells were washed in phosphate buffered saline, resuspended in extraction buffer (100 mM Tris, $\mathrm{pH}$ 8; 100 mM EDTA; $250 \mathrm{mM} \mathrm{NaCl}$ ), and disrupted by grinding in sterile glass homogenizers. DNA was then extracted using the DNeasy Plant Kit (Qiagen) as per manufacturer's instructions. Each PCR reaction contained $1 \mathrm{pg}$ cloned QPX SSU rDNA, $10 \mathrm{ng}$ cloned SSU rDNA from uninfected clams, 20 pg genomic DNA of cultured QPX cells, 30 to $40 \mathrm{ng}$ genomic DNA from infected and uninfected clams, or 100 pg genomic DNA of cultured thraustochytrid cells. All PCR reactions that did not generate product were re-amplified; $1 \mu l$ of unpurified PCR reaction was added to a fresh reaction mixture and cycled as described above.

Sensitivity of the QPX-F + QPX-R2 PCR assay was determined using cloned SSU rDNA and genomic DNA from cultured QPX cells. PCR reactions contained 10-fold serial dilutions of template, ranging from $100 \mathrm{pg}$ to $0.1 \mathrm{fg}$ for the cloned SSU rDNA and $2 \mathrm{ng}$ to $2 \mathrm{fg}$ for the genomic DNA. DNA concentrations were determined using a DyNA Quant 200 fluorometer (Hoefer Pharmacia Biotech).

Evaluation of probe sensitivity and specificity. Sequences of QPX and labyrinthulomycete DNA probes are listed in Table 1. Initial evaluations of the sensitivity and specificity of the candidate QPX probes were conducted using archived paraffinembedded clam tissues that were collected from

Table 1. Sequences and target regions of PCR primers and DNA probes. QPX primers and probes were designed to be specific for QPX, LABY primers and probes were designed to offer broader specificity for members of the phylum Labyrinthulomycota. SSU rDNA: small-subunit ribosomal DNA

\begin{tabular}{|llc|}
\hline $\begin{array}{l}\text { Primer/probe } \\
\text { name }\end{array}$ & \multicolumn{1}{c|}{ Sequence $\left(5^{\prime} \rightarrow 3^{\prime}\right)$} & $\begin{array}{c}\text { Target bases } \\
\text { in QPX SSU rDNA }\end{array}$ \\
\hline PCR primers & & \\
QPX-F & ATCCTCGGCCTGCTTTTAGTAG & $674-695$ \\
QPX-R2 & GAAGTCTCTACCTTTCTTGCGA & $1318-1339$ \\
LABY-A & GGGATCGAAGATGATTAG & $944-961$ \\
LABY-Y & CWCRAACTTCCTTCCGGT & $1361-1378$ \\
DNA probes & & \\
QPX641 & GATGACACACAGCAAACATTGACATT $641-666$ \\
QPX674 & CTACTAAAAGCAGGCCGAGGAT & $674-695$ \\
QPX1318 & GAAGTCTCTACCTTTCTTGCGA & $1318-1339$ \\
LABY1336 & AACCCGAAATGTCCCTCTAAGAAG & $1336-1359$ \\
\hline
\end{tabular}


Black Narrows, Chincoteague Bay, Virginia (VA) in fall 1996 (C-477) and from Burton Bay, VA, in spring 1998 (C-1895). Subsequent evaluations incorporated clam samples histologically diagnosed as QPXinfected from New Jersey (NJ), Massachusetts (MA), and Canada (CAN). MA clams were collected from Duxbury $(\mathrm{n}=4)$, NJ clams were collected from Great Bay $(\mathrm{n}=6)$ and CAN clams were collected from St. Andrews, New Brunswick $(n=2)$. Fixation of tissues varied with location: VA and NJ clams were fixed in Davidsons' AFA; MA clams were fixed in $10 \%$ neutral buffered formalin; and CAN clams were fixed in glutaraldehyde.

Paraffin-embedded tissues were sectioned at $5 \mu \mathrm{m}$ using a microtome. The sections were kept in order as they were cut and the consecutive sections numbered on the slides. Selected sections were stained with Harris hematoxylin and eosin (H\&E) and coverslipped. Adjacent sections were prepared for in situ hybridizations (ISH). Tissue sections for ISH were mounted on positively charged slides (Fisher Scientific) and treated as described below. The microtome blade and forceps were cleaned with xylenes between samples in order to prevent DNA carry-over contamination. ISH assays for specific detection of QPX were performed with DNA probes QPX641, QPX674, and QPX1318 (see Table 1). All probes were tested separately, and QPX641 and QPX1318 were later combined and used as a hybridization cocktail. When applied separately, hybridization solutions contained $5 \mathrm{ng}^{-1}$ of probe. The hybridization cocktail contained $4 \mathrm{ng} \mathrm{\mu l}^{-1}$ of each probe. ISH for general detection of labyrinthulomycetes was conducted with DNA probe LABY1336 at $5 \mathrm{ng}^{-1} \mathrm{l}^{-1}$. ISH was conducted as described previously (Stokes \& Burreson 1995), with Bismarck Brown Y counter-stain and coverslip modifications (Stokes \& Burreson 2001).

Additional specificity evaluations were conducted with cell smears of the thraustochytrids Schizochytrium aggregatum, Thraustochytrium aureum, and T. striatum. Cells were applied to positively charged slides, allowed to dry for $15 \mathrm{~min}$, then soaked in $8 \%$ paraformaldehyde overnight in a humid chamber. The fixative was decanted, and the slides were rinsed in TE buffer 3 times, air-dried, and subjected to ISH as described above.

Sequencing of geographically distinct samples. QPX SSU rDNA from selected VA, NJ, and MA infected clams was sequenced to examine molecular similarities. Two $5 \mu \mathrm{m}$ thick tissue sections per clam were scraped off the slides into a microcentrifuge tube using a sterile razor blade. Total genomic DNA was isolated from the paraffin-embedded tissues after deparaffinization and extended lysis in a Proteinase K detergent solution, as previously described (Vachot \&
Monnerot 1996). Genomic DNA from each sample was PCR amplified with the 3 primer pairs, QPX-F + QPXR2, LABY-A + QPX-R2, and LABY-A + LABY-Y, as described above. PCR products from the LABY-A + LABY-Y reactions were cloned and at least 5 clones per sample were sequenced, as described for QPX SSU rDNA.

Phylogenetic analyses. Both distance and parsimony analyses were done to examine taxonomic affinities based on DNA sequences from the organisms identified as QPX. Nearly full-length SSU rDNA sequence data were available for $3 \mathrm{QPX}$ isolates. Two sequences were previously deposited in GenBank. One sequence was from a MA QPX isolate used in a previous study (Maas et al. 1999, AF155209) and another was from a CAN QPX isolate (Ragan et al. 2000, AF261664). The third nearly full-length SSU rDNA sequence was from the MA cultured QPX isolate used in this study. The $\sim 435 \mathrm{bp}$ SSU rDNA fragment resulting from the LABY-A + LABY-Y amplifications of QPX DNA samples from histological sections of infected clams from VA, NJ and MA was used in phylogenetic analyses with homologous fragments from other taxa (A-Y fragments) where data were available. Pairwise distances were calculated with PAUP* 4 b8.0 (Swofford 2001) for the members of the Labyrinthulomycota with both DNA datasets. These distances were used to examine the relationships among sequences from the same species, species within a single genus and, for the A-Y fragments, the sequences from the geographically distinct isolates identified as QPX.

Phylogenetic analyses were performed with SSU rDNA sequences from the QPX samples, other members of the Labyrinthulomycota listed above and recently deposited sequences, which included sequences for new species and additional distinct SSU sequences for species already in GenBank. Recently deposited sequences for Thraustochytrium motivum (AF265337), Thraustochytrium sp. (AB052556), T. striatum (AF265338), Labyrinthula yorkensis (AF265333), L. zosterae (AF265334, AF265335), Labyrinthula spp. (AF265330, AF265332), Labyrinthuloides minuta (AF265339), Schizochytrium aggregatum (AF265336), and several sequences simply designated Thraustochytriidae spp. (AF2577314, AF257315, AF257316, AF257317) were included in the analyses. Two other stramenopiles, Achlya bisexualis (M32705) and Ochromonas danica (M32704) and the alveolates Oxytricha nova (X03948) and Prorocentrum minimum (Y16238) were used as outgroup taxa.

Sequences were aligned using the CLUSTAL-W algorithm (Thompson et al. 1994) in the MacVector 7.0 DNA Sequence Analysis Software package. Neighbor joining and parsimony jackknife analysis 
were performed using PAUP* $4 \mathrm{~b} 8.0$ (Swofford 2001). Neighbor joining trees were constructed based on uncorrected ' $\mathrm{p}$ ' distances. Parsimony jackknife was done with 100 bootstrap resamplings of 100 random addition replicates with gaps treated either as missing data or as a 5th base. Taxa with only partial sequences for the region of the SSU rDNA being examined were excluded from the distance analyses and any parsimony analyses treating gaps as a 5th base.

Field validation of QPX PCR assay. Cultured hard clams $(\mathrm{n}=25)$ were collected from planted beds of mixed stocks ( 2 to 4 yr old) located in Burton Bay, Virginia, on 9 occasions between February 2000 and June 2001 (see Table 3). Each clam was diagnosed for QPX using both standard histological techniques and PCR. Clams were shucked, and approximately $0.125 \mathrm{~g}$ of mantle tissue was carefully dissected using a flamesterilized scalpel and placed in TE buffer for DNA extraction and PCR. Then a cross section of each clam, which included pericardial cavity, intestine, stomach, digestive diverticula, gill, mantle, and foot, was fixed in $10 \%$ neutral-buffered formalin for histological examination.

Histological processing followed standard protocols, paraffin-embedded tissues were sectioned at $5 \mu \mathrm{m}$, stained with H\&E, and examined with a light microscope for the presence of QPX. The presence and distribution of QPX in each tissue or organ was characterized as focal, multifocal, or diffuse. The infection intensity, or number of viable parasites per tissue section, was estimated as rare (1-10), light (11-100), moderate (100-1000), or heavy ( $>1000)$.

For PCR, total genomic clam DNA was isolated from approximately $125 \mathrm{mg}$ clam mantle tissue by GTC (Yarnall et al. 2000) for all 9 samplings. For the last collection date, an additional $50 \mathrm{mg}$ mantle tissue was dissected and total genomic DNA isolated using the QIAamp ${ }^{\circledR}$ DNA Mini Kit (Qiagen). Tissue was lysed overnight at $56^{\circ} \mathrm{C}$ with gentle shaking and DNA purified as per manufacturer's instructions. Genomic DNA from both methods was PCRamplified using primers QPX-F + QPXR2 as described above. An aliquot of each reaction (10\% of reaction volume) was checked by agarose gel electrophoresis for the expected product size of $665 \mathrm{bp}$. Samples that were negative for QPX were reamplified by PCR. For reamplification, $1 \mu \mathrm{l}$ of the reaction mix from the initial PCR reaction served as the template DNA.

\section{RESULTS}

\section{Molecular diagnostics}

Genomic DNA was extracted from in vitro cultured QPX cells and the SSUr DNA was amplified by PCR using universal SSU primers for eukaryotic organisms. The amplicon was cloned, and multiple clones were sequenced. The derived QPX SSU rDNA sequence was $1745 \mathrm{bp}$.

Several sequence regions were identified for the development of probes and primers (Table 1). Two sets of primer pairs were designed. The first set, QPX-F and QPX-R2, was designed to be specific for QPX and amplified a $665 \mathrm{bp}$ region of the QPX SSU rDNA. It detected as low as $1 \mathrm{fg}$ cloned QPX SSU rDNA and 20 fg QPX genomic DNA in a single amplification (Fig. 1). Primer pair QPX-F and QPX-R2 was specific in that it did not amplify DNA of uninfected host or any of the 3 thraustochytrids tested-Schizochytrium aggregatum, Thraustochytrium aureum, and T. striatum (Fig. 1).

The second primer pair, LABY-A and LABY-Y, was designed to offer broader specificity for the phylum Labyrinthulomycota and amplified approximately $435 \mathrm{bp}$ of SSU rDNA (A-Y fragment) from QPX and the 3 thraustochytrids, but not host DNA (Fig. 2). Pairing one of the QPX-specific primers with one of the labyrinthulomycete primers, LABY-A and QPX-R2, maintained specificity for QPX while targeting a smaller region of $395 \mathrm{bp}$.

Several DNA probes were evaluated for use in in situ hybridization (ISH) assays of cell smears and paraffinembedded tissues. Probes QPX674 and QPX1318

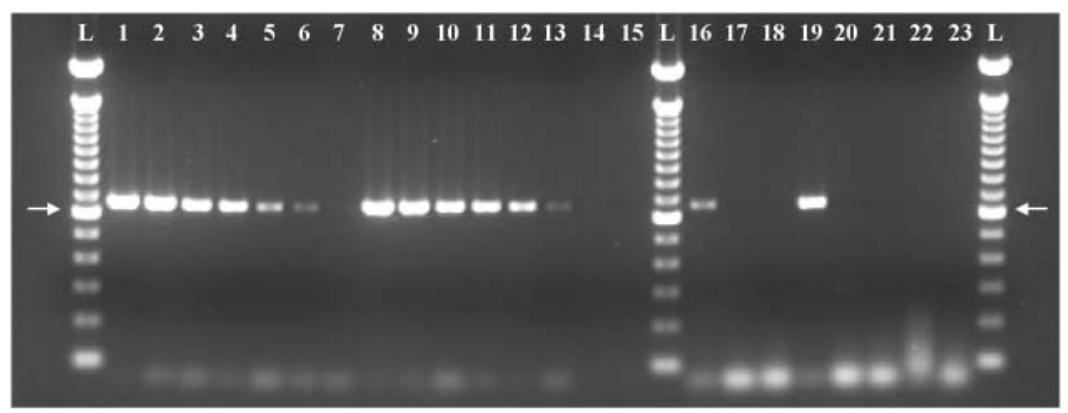

Fig. 1. PCR amplification with primers QPX-F and QPX-R2. Lanes 1 to 14 demonstrate sensitivity and lanes 16 to 23 demonstrate specificity of the PCR assay. Lanes L: $100 \mathrm{bp}$ ladder, arrows indicate $600 \mathrm{bp}$; lanes 1 to 7 : serial dilutions of cloned QPX SSU rDNA: 100 pg, 10 pg, 1 pg, 100 fg, 10 fg, 1 fg, 0.1 fg template DNA, respectively; lanes 8 to 14: serial dilutions of genomic DNA from QPX-cultured cells: $2 \mathrm{ng}, 200 \mathrm{pg}$, 20 pg, 2 pg, $200 \mathrm{fg}, 20 \mathrm{fg}$, $2 \mathrm{fg}$ template DNA, respectively; lane 15: control (no DNA); lane 16: QPX-infected clam genomic DNA; lane 17: uninfected clam genomic DNA; lane 18: cloned clam small-subunit ribosomal DNA (SSU rDNA); lane 19: QPX-cultured cells genomic DNA; lane 20: Schizochytrium aggregatum genomic DNA; lane 21: Thraustochytrium aureum genomic DNA; lane 22: T. striatum genomic DNA; lane 23: control (no DNA). PCR reactions loaded in lanes 17, 18, 20, 21,22 , and 23 were reamplifications 


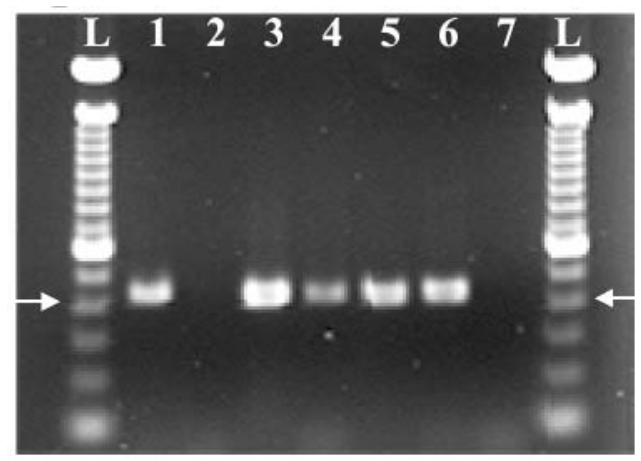

Fig. 2. PCR amplification with primers LABY-A and LABY-Y. Lanes L: $100 \mathrm{bp}$ ladder, arrows indicate $400 \mathrm{bp}$; lane 1: QPXinfected clam genomic DNA; lane 2: uninfected clam genomic DNA; lane 3: QPX cultured cells genomic DNA; lane 4: Schizochytrium aggregatum genomic DNA; lane 5: Thraustochytrium aureum genomic DNA; lane 6: T. striatum genomic DNA; lane 7: control (no DNA). PCR reactions loaded in lanes 2 and 7 were reamplifications

(same target regions as primers QPX-F and QPX-R2, respectively), as well as probe QPX641, were tested for QPX specificity (Table 1). Probe LABY1336, which was designed to offer broader specificity to hybridize with any member of the phylum Labyrinthulomycota, was evaluated for hybridization with QPX, Schizochytrium aggregatum, Thraustochytrium aureum, and T. striatum (Table 1).

DNA probe QPX674 was quickly discarded as it did not hybridize with QPX cells. Initial trials of the other 2 QPX DNA probes, QPX641 and QPX1318, produced variable results, as the probes failed to hybridize with all infected clam samples tested, and sometimes failed

Table 2. Origin and identification of samples tested for QPX by in situ hybridization (ISH). ISH results using a single QPX probe and QPX probe cocktail are contrasted. Samples originated from Virginia (VA), New Jersey (NJ), Massachusetts (MA), and New Brunswick, Canada (CAN). Hybridization signal intensities denoted as negative (-), weak (+/-), moderate $(+)$, and strong $(++)$; ND: not done

\begin{tabular}{|lcccc|}
\hline $\begin{array}{l}\text { Sample } \\
\text { identification }\end{array}$ & Origin & $\begin{array}{c}\text { Hybridization } \\
\text { using probe } \\
\text { QPX641 }\end{array}$ & $\begin{array}{c}\text { Hybridization } \\
\text { using probe } \\
\text { QPX1318 }\end{array}$ & $\begin{array}{c}\text { Hybridization } \\
\text { using QPX } \\
\text { probe cocktail }\end{array}$ \\
\hline C-477A & VA & + & ++ & ++ \\
C-1048 & VA & - & - & ++ \\
C-1895 & VA & ND & + & ++ \\
$9844-8$ & NJ & - & - & $+/-$ \\
$9844-29$ & NJ & - & - & + \\
$9847-25$ & NJ & ND & - & $+/-$ \\
$9545-5$ & MA & + & + & ++ \\
$9545-6$ & MA & ND & ++ & ++ \\
$9545-8$ & MA & ND & + & ++ \\
$9545-19$ & MA & - & - & $+/-$ \\
20 & CAN & ND & ++ & ++ \\
$24 \mathrm{~A}$ & CAN & ND & ++ & ++ \\
\hline
\end{tabular}

to hybridize with all QPX cells within a particular tissue section (Table 2). Various steps of the ISH protocol (e.g. probe concentration, type and concentration of protease, hybridization temperature) were altered in an attempt to improve hybridization; however, these alterations did not significantly enhance the results. This problem was finally overcome by utilizing a hybridization cocktail that contained both probes QPX641 and QPX1318. Utilization of the probe cocktail greatly enhanced the technique's sensitivity. The probe cocktail consistently hybridized to QPX in tissues of hard clams collected from VA, NJ, MA, and CAN (Table 2, Fig. 3). ISH labeling of the QPX cells in clams from VA, MA and CAN was very intense when the probe cocktail was applied. QPX cells in the NJ clams hybridized with the probe cocktail, but not as intensely as those in samples from the other locations. Regardless of collection location, hybridization was absent or less intense when probes QPX641 and QPX1318 were used independently than when the probe cocktail was used (Table 2). The QPX probe cocktail did not hybridize with clam tissue or with cell smears of the 3 thraustochytrids (Figs. $3 \& 4$ ). The general labyrinthulomycete DNA probe LABY1336 hybridized with QPX in histological sections of infected clams and with cell smears of Schizochytrium aggregatum, Thraustochytrium aureum, and T. striatum (Fig. 4).

In order to examine the molecular similarity of the QPX organisms originating from $\mathrm{VA}, \mathrm{NJ}$, and MA, genomic DNA was isolated from paraffin-embedded tissues of infected clam samples, amplified using LABY-A and LABY-Y primers, cloned, and sequenced. The resultant sequences of the targeted region (bases 944 to 1378) were identical to the QPX SSU rDNA sequence initially generated in this study, except for a transition at base 1072 in the NJ sample. The base change from $A$ to $G$ was in all the clones sequenced for this sample location and was not within the annealing site of any QPX probe or primer.

\section{Phylogenetic analyses}

Results of phylogenetic analyses with both the nearly full-length and truncated (A-Y fragment) rDNA sequence datasets supported earlier studies that had employed fewer taxa (Maas et al. 1999, Ragan et al. 2000), which placed QPX in the phylum Labyrinthulomycota as a sister taxon to Thraustochytrium pachydermum (Ragan et al. 


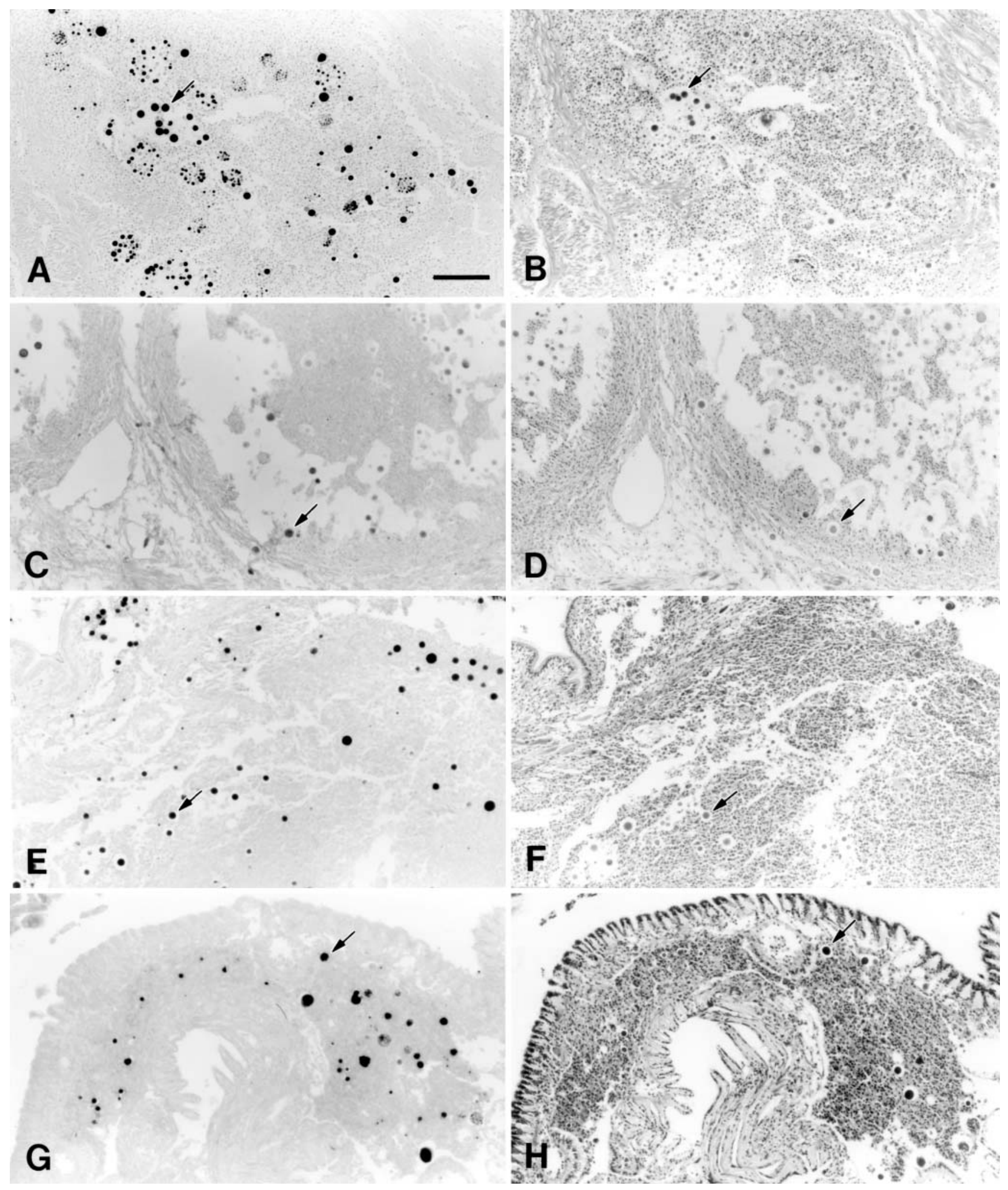

Fig. 3. Detection of QPX cells in consecutive histological sections of clams from various geographic sites using in situ hybridization (ISH) with QPX641 and QPX1318 probe cocktail $(\mathrm{A}, \mathrm{C}, \mathrm{E}, \mathrm{G})$ and hematoxylin and eosin $(\mathrm{H} \& \mathrm{E})$ stain $(\mathrm{B}, \mathrm{D}, \mathrm{F}, \mathrm{H})$. Clams were collected from $(A, B)$ Virginia, $(C, D)$ New Jersey, $(E, F)$ Massachusetts, and $(G, H)$ New Brunswick. Arrows indicate QPX cells. Scale bar $=100 \mu \mathrm{m}$ (all panels) 


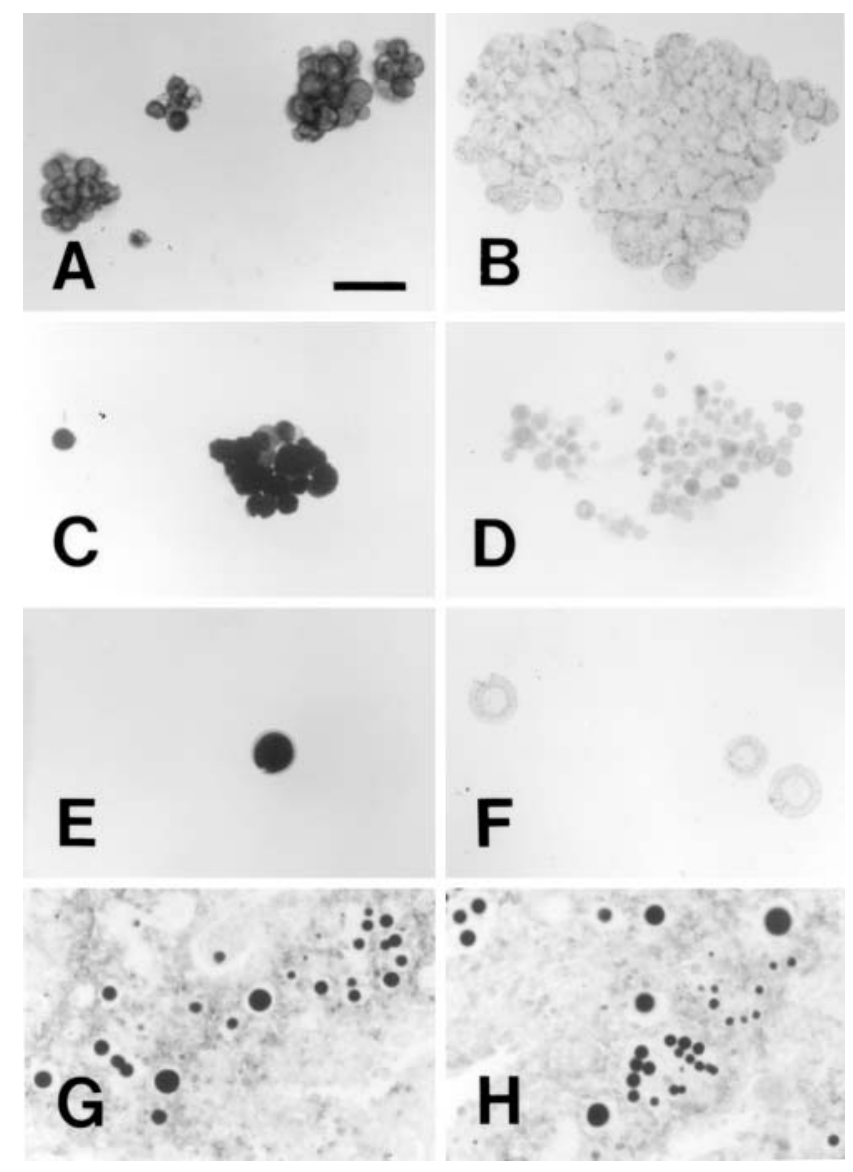

Fig. 4. ISH of various thraustochytrids with the general labyrinthulomycete probe LABY1336 $(\mathrm{A}, \mathrm{C}, \mathrm{E}, \mathrm{G})$ and the QPX DNA probe cocktail $(\mathrm{B}, \mathrm{D}, \mathrm{F}, \mathrm{H})$. Cell smears of $(\mathrm{A}, \mathrm{B})$ Schizochytrium aggregatum, $(\mathrm{C}, \mathrm{D})$ Thraustochytrium aureum, and $(\mathrm{E}, \mathrm{F})$ T. striatum and $(\mathrm{G}, \mathrm{H})$ histological section of QPX-infected clam from Virginia. Scale bar $=50 \mu \mathrm{m}$ (all panels)

2000) (Figs. 5 \& 6). With a reduced taxonomic dataset, consisting of only taxa with nearly full-length SSU rRNA gene sequences, all QPX sequences grouped together with parsimony jackknife support of 100 . Using either the alveolates or other stramenopiles as outgroup taxa, the phylum was monophyletic (trees with alveolates not shown).

Topologies of the distance and parsimony trees were similar (Figs. $5 \& 6$ ). In parsimony analysis with the complete taxonomic dataset, which included some taxa for which approximately two-thirds ( 1200 bp) of the SSU rRNA gene sequence was available and those taxa with nearly full-length SSU rDNA sequences, gaps were treated as missing, and 1452 of 1954 sites were parsimony informative (Fig. 5A). With the reduced taxonomic dataset, which included only taxa for which nearly full-length SSU rDNA sequences were available, gaps were treated as a 5 th base, and 738 of 1829 sites were parsimony informative (Fig. 5B).
Ninety-seven of 410 sites were found to be parsimony informative with the A-Y fragment dataset (Fig. 6A). The Labyrinthulomycota taxa fell into 2 major phylogenetic groups in the neighbor joining analysis (Figs. 5C \& 6B). This result was consistent with the 2 major phylogenetic groupings within the Labyrinthulomycota, the thraustochytrid phylogenetic group (TPG) and the labyrinthulid phylogenetic group (LPG), described by Honda et al. (1999). Parsimony jackknife support was relatively strong for the TPG and LPG groups with both the nearly full-length SSU rDNA (Fig. 5A,B) and the A-Y fragment (Fig. 6A) datasets. Analysis using the nearly full-length SSU rDNA dataset with the more inclusive taxonomic composition, which included some taxa with shorter SSU rDNA sequences, also supported the TPG and LPG but placed several species of the Labyrinthula genus into a third group (the Labyrinthula species group) that was sister to the other members of the phylum. The parsimony jackknife support value for this third grouping was relatively high (88, Fig. 5A). Interestingly, in both distance and parsimony analyses, QPX, Thraustochytrium pachydermum and often 2 of the Thraustochytriidae spp. sequences fell into a clade that was separate, but sister to, the other taxa in the TPG (Figs. 5B,C \& 6). Sequences that were presumably from the same species often did not group together in these phylogenetic analyses. In addition, species currently placed in the same genus (e.g. Labyrinthuloides minuta and L. haliotidis, Fig. 5A) could often be found in 2 distinct phylogenetic groupings (Figs. 5 \& 6).

Pairwise distances were calculated for the labyrinthulomycete taxa to determine if there was reasonable support from the SSU rDNA sequence data for the QPX samples from geographically distinct sites being from the same, or at least closely related, species by comparison to pairwise distances within and among the other species and genera in the Labyrinthulomycota. A-Y fragment data were available for all of the QPX samples, while for other taxa in the phylum more complete sequence data were available and pairwise (' $\mathrm{p}$ ') distances were calculated for overlapping regions that could be aligned. QPX A-Y fragments had uncorrected ' $\mathrm{p}$ ' distances ranging from 0-0.00501, which corresponded to 0-2 nucleotide differences across a total of 411 characters. The 2 Ulkenia profunda sequences, however, showed a ' $\mathrm{p}$ ' distance of 0.08613 in the $\mathrm{A}-\mathrm{Y}$ fragment region, corresponding to more nucleotide differences. On the other hand, a ' $\mathrm{p}$ ' distance of only 0.00767 was observed for the A-Y fragment between 2 species that are currently placed in different genera, Japonochytrium sp. and U. visurgensis. The pairwise distances among species of the genus Ulkenia ranged from 0.00251 to 0.09084 , while among Thraustochytrium species distances were generally 
A

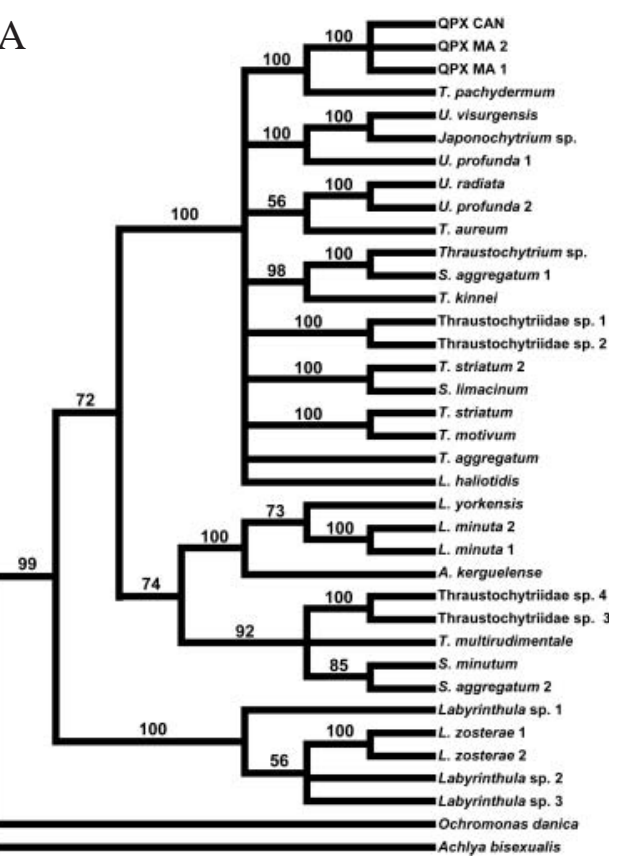

B

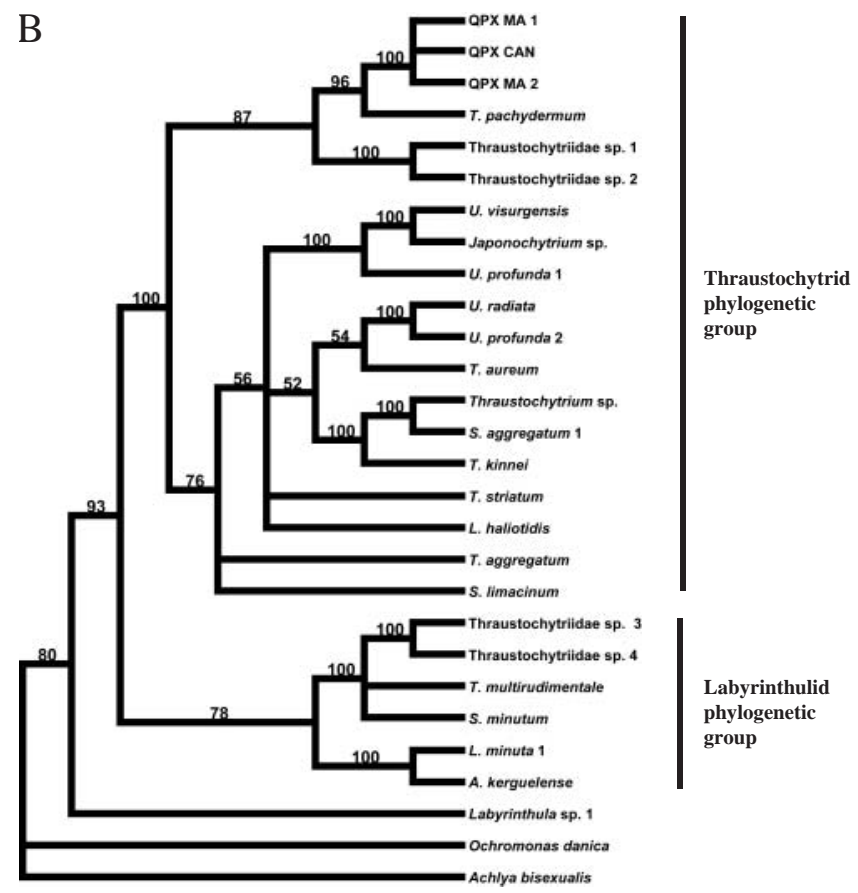

greater, ranging between 0.06516 and 0.13393 for the A-Y fragment. For the nearly full-length SSU rDNA QPX sequences from the CAN and MA isolates, ' $p$ ' distances ranged from 0 to 0.00062 , demonstrating very few nucleotide differences among the sequences. The uncorrected ' $\mathrm{p}$ ' distance between Japonochytrium sp. and $U$. visurgensis across this nearly full-length gene sequence was 0.00246 , while the distances among Ulkenia species were much greater, ranging from 0.06196 to 0.12568 and among Thraustochytrium spe-

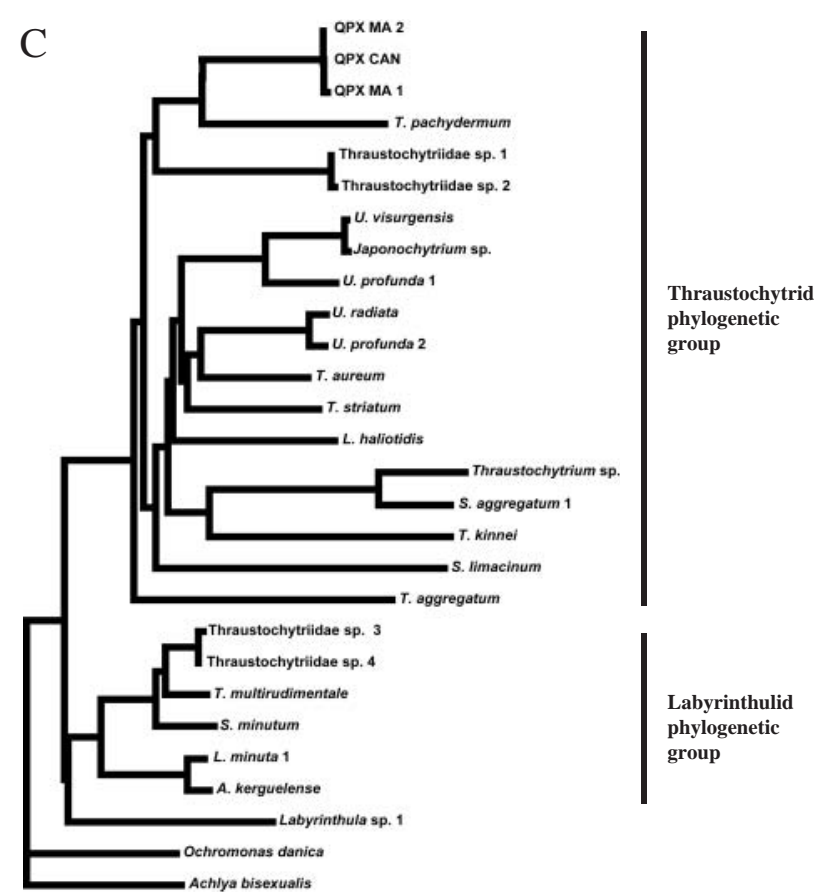

Fig. 5. Phylogenetic trees based on nearly full-length SSU rDNA sequences. For the parsimony trees, support values above 50 are shown on branches. (A) Parsimony jackknife consensus tree based on analysis of the complete labyrinthulomycete taxonomic dataset, which included some taxa with shorter (approximately 1200 bp) SSU rDNA sequences. Analysis was conducted with 100 jackknife replicates of 100 random additions and gaps treated as missing data. (B) Parsimony jackknife consensus tree based on analysis of the reduced labyrinthulomycete taxonomic dataset, which included only those taxa with nearly full-length SSU rDNA sequences. Analysis was conducted with 100 jackknife replicates of 100 random additions and gaps treated as a 5th base. (C) Neighbor joining tree based on uncorrected ' $p$ ' distances resulting from analysis of the reduced labyrinthulomycete taxonomic dataset

cies there were very high ' $\mathrm{p}$ ' distances, ranging from 0.15425 to 0.23224 . (Complete pairwise distance data available on request.)

\section{Field validation}

Clams ( $\mathrm{n}=224)$ were examined for QPX in field validation trials using both standard histology and PCR of guanidine thiocyanate lysis (GTC) DNA. Standard his- 

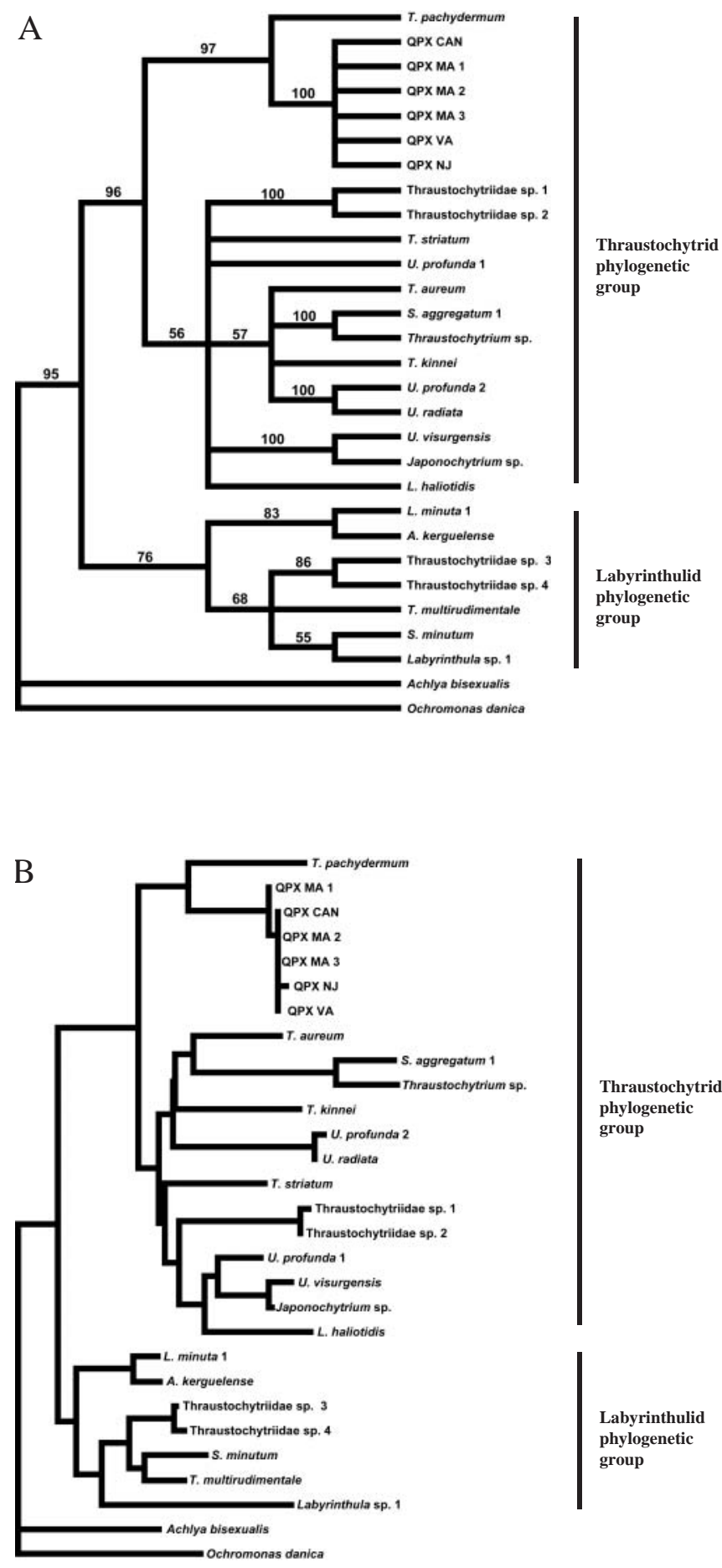

Fig. 6. Phylogenetic trees generated based on the A-Y fragment of the SSU rDNA sequences. For the parsimony tree, support values above 50 are shown on branches. (A) Parsimony jackknife consensus tree based on analysis with 100 jackknife replicates of 100 random additions and gaps treated as a 5th base. (b) Neighbor joining tree resulting from analysis based on uncorrected ' $\mathrm{p}$ ' distances tology detected QPX in 35/224 (16\%) of the clams while PCR detected QPX in 22/224 (10\%) (Table 3). Sixty percent (21/35) of clams diagnosed as positive by histology were falsely diagnosed as negative by initial PCR assays. In most instances false negative PCR diagnoses occurred in clams with infections that were diagnosed as focal, and rare to light in intensity by histology (Fig. 7). PCR failed to detect $81 \%$ of the rare infections and $53 \%$ of the light infections. Eight of the $22(36 \%)$ clams that tested positive by PCR were negative by histology. The frequency of positives and negatives did not significantly differ $\left(\chi^{2}=0.069, p=0.7923\right.$, $\mathrm{df}=1$ ) between the 2 diagnostic methods.

Reamplification of the PCR products that were initially determined to be negative for QPX improved the sensitivity of the assay. Upon reamplification PCR detected 7 additional infections that were also positive by histology and 4 that were negative by histology (Table 4). The infections that were positive by histology were ranked as focal and rare (Fig. 7). The increased detection efficacy that was brought about by reamplification resulted in nearly equivalent determinations of QPX prevalence between the 2 methods$35 / 224(15.6 \%)$ by histology and 33/224 (14.7\%) by PCR (Table 4). PCR detection of infections, scored as focal by histology, increased from 20 to $48 \%$, and PCR detection of infections, scored as rare by histology, increased from 19 to $63 \%$ (Fig. 7). There was no increase in the detection by PCR of infections ranked as light by histology. Interestingly, there were still numerous cases in which infections were detected by one method and not the other (Table 4).

The effect of DNA isolation technique on PCR diagnosis was tested on the last group of clams collected for the field validation study. These clams were experiencing mortalities, presumably due to QPX. Genomic DNA was isolated from clam tissue using GTC, in the same manner as for the previous 8 samplings, and the QIAamp ${ }^{\circledR}$ DNA Mini Kit (QIA). Standard histology detected QPX in 10/25 (40\%) of the clams while initial PCR amplification detected QPX from GTC DNA in 8/25 (32\%) and from QIA DNA in 11/25 (44\%) (Table 5). Reamplification of the PCR-negative samples increased the number of QPX-positive clams for both DNA isolation techniques: GTC DNA detected 4 additional infections and QIA DNA detected 5 additional infections, for a combined PCR detection of QPX in 48 and $64 \%$ of the clams, respectively. Two infections positive by histology were negative by PCR regardless of DNA preparation; these infections were ranked as focal light and focal rare (1 cell). Comparison of PCR results from the 2 DNA isolation methods suggest that QIA may be more sensitive, since PCR with this DNA detected more QPX infections overall as well as more of the infections diagnosed by histology, especially before reamplification; however, 
Table 3. Comparison of observed frequencies of positive and negative diagnoses of QPX made by PCR and histology (Histo). PCR diagnosis based on a single amplification reaction of genomic DNA prepared by guanidine thiocyanate lysis

\begin{tabular}{|lcccc|}
\hline $\begin{array}{l}\text { Sample } \\
\text { date }\end{array}$ & $\begin{array}{c}\text { PCR negative } \\
\text { Histo negative }\end{array}$ & $\begin{array}{l}\text { PCR negative } \\
\text { Histo positive }\end{array}$ & $\begin{array}{c}\text { PCR positive } \\
\text { Histo negative }\end{array}$ & $\begin{array}{c}\text { PCR positive } \\
\text { Histo positive }\end{array}$ \\
\hline 16 Feb 00 & 25 & 0 & 0 & 0 \\
4 May 00 & 12 & 5 & 0 & 8 \\
19 Jul 00 & 25 & 0 & 0 & 0 \\
1 Aug 00 & 18 & 6 & 1 & 0 \\
12 Sep 00 & 23 & 1 & 0 & 1 \\
1 Nov 00 & 20 & 1 & 1 & 3 \\
1 Feb 01 & 24 & 0 & 0 & 0 \\
21 May 01 & 25 & 0 & 0 & 0 \\
5 Jun 01 & 9 & 8 & 6 & 2 \\
Total & 181 & 21 & 8 & 14 \\
\hline
\end{tabular}

Table 4. Comparison of observed frequencies of positive and negative diagnoses of QPX made by PCR and histology (Histo) after PCR reamplification of samples initially diagnosed as negative by PCR

\begin{tabular}{|lcccc|}
\hline $\begin{array}{l}\text { Sample } \\
\text { date }\end{array}$ & $\begin{array}{c}\text { PCR negative } \\
\text { Histo negative }\end{array}$ & $\begin{array}{c}\text { PCR negative } \\
\text { Histo positive }\end{array}$ & $\begin{array}{c}\text { PCR positive } \\
\text { Histo negative }\end{array}$ & $\begin{array}{c}\text { PCR positive } \\
\text { Histo positive }\end{array}$ \\
\hline 16 Feb 00 & 25 & 0 & 0 & 0 \\
4 May 00 & 9 & 2 & 3 & 11 \\
19 Jul 00 & 25 & 0 & 0 & 0 \\
1 Aug 00 & 17 & 6 & 2 & 0 \\
12 Sep 00 & 23 & 1 & 0 & 1 \\
1 Nov 00 & 20 & 1 & 1 & 3 \\
1 Feb 01 & 24 & 0 & 0 & 0 \\
21 May 01 & 25 & 0 & 0 & 6 \\
5 Jun 01 & 9 & 4 & 6 & 21 \\
Total & 177 & 14 & 12 & \\
\hline
\end{tabular}

Table 5. Comparison of observed frequencies of positive and negative PCR diagnoses of QPX as influenced by DNA isolation method for the 5 June 2001 samples. Samples diagnosed by guanidine thiocyanate DNA isolation and PCR amplification (GTC), QIAamp® kit DNA isolation and PCR amplification (QIA), and histology (Histo). GTC-1 and QIA-1: PCR diagnoses based on single amplification reaction; GTC-2 and QIA-2: PCR diagnoses after reamplification of initially negative samples

\begin{tabular}{|lcccc|}
\hline $\begin{array}{l}\text { DNA isolation } \\
\text { method }\end{array}$ & $\begin{array}{c}\text { PCR negative } \\
\text { Histo negative }\end{array}$ & $\begin{array}{c}\text { PCR negative } \\
\text { Histo positive }\end{array}$ & $\begin{array}{r}\text { PCR positive } \\
\text { Histo negative }\end{array}$ & $\begin{array}{c}\text { PCR positive } \\
\text { Histo positive }\end{array}$ \\
\hline GTC-1 & 9 & 8 & 6 & 2 \\
QIA-1 & 10 & 4 & 5 & 6 \\
GTC-2 & 9 & 4 & 6 & 6 \\
QIA-2 & 6 & 3 & 9 & 7 \\
& & & & \\
& GTC negative & GTC negative & GTC positive & GTC positive \\
& QIA negative & QIA positive & QIA negative & QIA positive \\
\hline 1st amplification & 12 & 5 & 2 & 6 \\
Reamplification & 7 & 6 & 2 & 10 \\
\hline
\end{tabular}

the difference between the 2 methods was not significant $\left(\chi^{2}=1.299\right.$, $\mathrm{p}=0.2545$, df $=1$ ).

\section{DISCUSSION}

The PCR primers QPX-F and QPX-R2 demonstrated both sensitivity and specificity for the QPX organism. The primer pair readily detected $1 \mathrm{fg}$ cloned QPX SSU rDNA or 20 fg QPX genomic DNA in a single amplification. The sensitivity of the amplification reaction to as little as $20 \mathrm{fg}$ of genomic DNA suggests that this technique could detect a very small number of QPX cells. PCR amplification of specific numbers of cells was not conducted because it has not been possible to accurately enumerate cells due to copious amounts of mucus released by QPX cells in culture. The primers did not amplify DNA of the host, Mercenaria mercenaria, or any of the 3 thraustochytrids, Schizochytrium aggregatum, Thraustochytrium aureum, and T. striatum, suggesting that they are specific for the QPX organism.

The more general PCR primers, LABY-A and LABY-Y, amplified DNA from the QPX organism and from the 3 thraustochytrids. The primer pair did not amplify hard clam DNA. Pairing one of the QPX specific primers (QPXR2) with one of the labyrinthulomycete primers (LABY-A) maintained specificity for QPX while targeting a smaller region of $395 \mathrm{bp}$, rather than the $665 \mathrm{bp}$ targeted by QPX-F and QPX-R2. Primer pairs that target relatively small regions of DNA are generally more efficient in amplifying DNA from formalinpreserved material; hence the LABY-A and QPX-R2 primer pair may be useful for this purpose.

Three DNA probes for ISH were developed and tested for QPX sensitivity and specificity. The first probe, QPX674 and PCR primer QPX-F, targeted QPX SSU rDNA bases 674 to 695 . This region worked well for PCR amplification of the nuclear rDNA but not for ISH, which primarily targets the SSU rRNA molecules. Presumably secondary structure within the SSU rRNA 

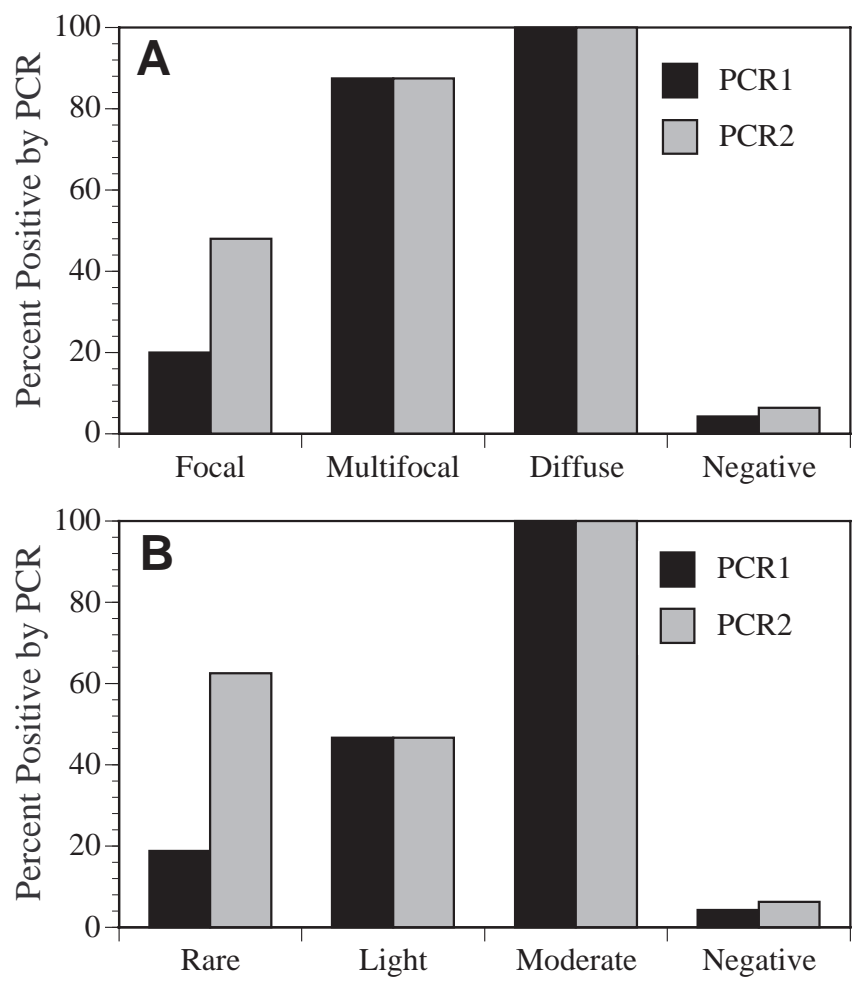

Fig. 7. Percent of QPX infections having (A) tissue distributions classified as focal, multifocal, diffuse, and negative and (B) intensities classified as rare, light, moderate, and negative by histological examination of field validation samples that were determined to be positive by initial (PCR 1) and reamplification (PCR 2) QPX PCR assays

may have limited access to the probe binding site. Highly variable results were obtained with the other 2 DNA probes designed to detect the QPX organism. However, a cocktail of both probes greatly improved detection in ISH assays, resulting in enhancement of the hybridization signal as reported by Trembleau \& Bloom (1995). The probe cocktail did not hybridize with host tissue or with 3 thraustochytrids tested, suggesting that the probe cocktail is specific for the QPX organism. Reasons for the signal variability associated with the individual probes are not clear. It is possible that the 2 probes hybridized with 2 different strains or species of histologically indistinguishable thraustochytrids within the samples. One or both of the general labyrinthulomycete primers may not be able to amplify the DNA of one of these histologically identical thraustochytrids. This would result in a PCR product representing only one of the strains or species of putative QPX organisms observed in the histological section. This is highly unlikely, however, given that these primers target conserved regions within the SSU rDNA of both labyrinthulids and thraustochytrids. Reduced variability associated with the probe cocktail, as opposed to the individual probes, is probably due to increased destabilization of SSU rRNA secondary structure by the presence of more than one oligonucleotide bound to the target molecule. The enhanced ISH sensitivity by multiple, non-overlapping probes yielded an additive signal with no increase in background for Trembleau \& Bloom (1995), and the QPX probe cocktail generated the same result in this study.

In recent years tremendous progress has been made in the development of molecular diagnostic techniques. Numerous PCR assays and oligonucleotide probes are now available for a variety of bivalve mollusc disease agents including Haplosporidium nelsoni (Fong et al. 1993, Stokes \& Burreson 1995, Stokes et al. 1995a, Ko et al. 1999, Day et al. 2000), H. costale (Ko et al. 1995, Stokes \& Burreson 2001), Minchinia teredinis (Stokes et al. 1995b), Mikrocytos roughleyi (Adlard \& Lester 1995), Marteilia sydneyi (Anderson et al. 1995, Kleeman \& Adlard 2000), Marteilia refringens (Le Roux et al. 1999), Perkinsus marinus (Marsh et al. 1995, Yarnall et al. 2000, Reece et al. 2001), and Bonamia ostreae (Carnegie et al. 2000, Cochennec et al. 2000). Discussions regarding the value of these novel molecular diagnostic tools generally cite high sensitivity and specificity, and the capability of producing a rapid and cost-effective diagnosis. However, before such benefits can be realized, it is important to conduct thorough field validations against traditional standard diagnostic techniques (Hiney \& Smith 1998). Field validation trials for the pathogens listed above have been limited. Studies by Stokes et al. (1996) and Carnegie et al. (2000) demonstrated molecular diagnostics for $H$. nelsoni and $B$. ostreae, respectively, to be more sensitive than diagnosis by histological examination.

In contrast, the QPX PCR primers developed here were not more sensitive than routine histological analysis. This result most likely relates to the fact that QPX infections are often focal or localized in clam tissues. Unlike some oyster parasites, it does not appear that QPX is dispersed through its host via circulatory activities. QPX cells are surrounded by viscous mucus that appears to retain clusters of parasitic cells focally. Hence, diffuse or systemic infections are less likely to occur. Sampling error is likely to be greater in the case of focal infections than systemic infections, as the chance of encountering infective cells in any particular subsample of tissue is reduced. False negative PCR assays were diagnosed as focal infections by histology; likewise, samples that were positive by PCR and negative by histology may have been focal infections located in the tissue used for DNA extraction. Given the focal nature of QPX infections, the error associated with tissue sampling should be evaluated. It may be that duplicate or triplicate tissue samples must be taken to improve the precision of PCR. 
The sensitivity of the PCR assay using QPX-F and QPX-R2 primers could potentially be improved by altering the tissue sampling and DNA isolation protocols. The latter was tested during the last month of the field validation study by comparison of DNA isolation using GTC and the QIA. The PCR assay using QIA DNA seemed to be more sensitive for QPX detection than PCR with GTC DNA, even though a smaller tissue sample is used. PCR of the QIA DNA also had better agreement with QPX-positive histology samples than GTC did, especially with one round of amplification; however, the number of clams used for this comparison was too small to definitively determine the effect of DNA isolation method on PCR diagnosis. The deviation in PCR results for GTC and QIA may also be related to tissue sampling; further comparison should be made using an experimental design that incorporates an estimate of such error. While the application of PCR-based diagnosis of QPX may have little advantage over histological analysis for routine monitoring of QPX disease in wild and cultured clam populations, it may prove very useful for research purposes.

QPX has been documented in hard clams from Virginia, New Jersey, and Massachusetts, USA, and Prince Edward Island, Nova Scotia, and New Brunswick, Canada; however, differences in the presentation of the disease, in terms of both QPX morphology and host response, has raised speculation that different species or strains of the organism may exist (Ragone Calvo et al. 1998, Smolowitz et al. 1998). The 1745 bp QPX SSU rDNA sequence presented here showed $99 \%$ similarity to the sequence reported by Maas et al. (1999), both of which were derived from in vitro cultures of QPX cells from diseased clams collected in Massachusetts, and to the sequence reported by Ragan et al. (2000), which was derived from an in vitro QPX culture from infected hard clams collected in New Brunswick, Canada. The QPX SSU rDNA sequence reported here differed from the previously published sequences by only 2 bases and 1 base, respectively. The close similarity of the sequences of QPX originating from Massachusetts and New Brunswick suggests that the 2 organisms are very similar, likely within the same genus and possibly the same species. Additionally, the QPX probe cocktail consistently hybridized with QPX cells in tissue sections of QPX-infected clams from all 3 USA sites as well as from Canada, providing supporting evidence that the organisms observed in these geographically distinct areas are genetically very closely related.

To corroborate this observation, QPX SSU rDNA sequences were determined for selected paraffinembedded infected hard clam samples from Virginia, New Jersey, and Massachusetts. Amplification of the Canadian material was unsuccessful, probably because of the glutaraldehyde fixation, which damages DNA. The sequences of the $435 \mathrm{bp}$ target region were identical for VA and MA samples and nearly identical for the NJ sample (single base change from VA/MA sequence). If any other labyrinthulomycete had been present in these samples, it also would have been amplified by the LABY-A and LABY-Y primers and subsequently sequenced. However, each of the 3 samples generated only 1 PCR product. Multiple DNA clones of the amplification product had identical sequences, suggesting that only 1 labyrinthulomycete, QPX, was present in each sample. The sequence similarity of the putative QPX organisms infecting hard clams from Virginia, New Jersey and Massachusetts supports the ISH results, which suggests the close relationship of these organisms.

Further assertions regarding the relatedness of geographically distinct QPX organisms requires phylogenetic analyses, including the determination of pairwise sequence distances. The phylogenetic analyses conducted for this study support earlier observations that QPX belongs within the Labyrinthulomycota (Whyte et al. 1994, Smolowitz et al. 1998, Maas et al. 1999, Ragan et al. 2000). Honda et al. (1999) examined the SSU rDNA of 6 genera of labyrinthulids and thraustochytrids and found signature sequences that provided separation into the 2 major phylogenetic groups, the TPG and LPG. The phylogenies presented here agree with those groupings, with QPX in the TPG. Analyses that included more recently deposited sequences for Labyrinthula species suggest that some members of that genus form a separate sister group to the major clade containing the TPG and LPG (Fig. 5).

Pairwise sequence distances for taxa within the Labyrinthulomycota were calculated to assess whether it was reasonable to claim, based on the SSU rDNA sequences, that the QPX samples from geographically distinct sites were likely to be the same species. Within some phyla, genera demonstrate great variability within portions of the SSU rDNA and sequence information aids in species determination. For example, the plasmodial life stages of Haplosporidium costale and $H$. nelsoni are difficult to differentiate by histological examination; however, with the use of SSU rDNA-based tools, these can be readily discriminated (Stokes \& Burreson 2001). In other phyla, inter-specific SSU rDNA sequences are highly conserved within a genus, so that species differentiation is difficult or not possible using this gene. This is true, for example, of Perkinsus species (Kotob et al. 1999, Reece et al. 2001), Marteilia species infecting mussels and oysters in Europe (Berthe et al. 2000, Le Roux et al. 2001), and of rhizocephalans that parasitize green crabs (Murphy \& Goggin 2000).

Pairwise distance comparisons and phylogenetic analyses conducted for this study, however, support as- 
sertions by other researchers that there needs to be a major reevaluation of the taxonomy for the phylum Labyrinthulomycota (Honda et al. 1999, Maas et al. 1999, Ragan et al. 2000). Labyrinthulomycete species currently placed in the same genus based on morphological characters have often failed to group together in molecular phylogenetic studies based on SSU rDNA sequences (Honda et al. 1999, Ragan et al. 2000). In this study, species in the same genus sometimes showed greater uncorrected ' $\mathrm{p}$ ' distances than was observed between species in different genera. In addition, it was found that in some cases, even sequences reportedly from the same species showed much greater pairwise distances than was observed among species currently placed in different genera. For example, in the region of SSU rDNA for which data were overlapping, 2 sequences for Schizochytrium aggregatum (AB022106 and AF265336) and those for Thraustochytrium striatum (AB022112 and AF265338) showed uncorrected 'p' distances of 0.27588 and 0.19909 , respectively. By contrast, however, in this same region the sequences for Japonochytrium sp. (AB022104) and Ulkenia profunda (L34054) had an uncorrected ' $\mathrm{p}$ ' distance of only 0.06762. The species identifications and/or sequence data need to be carefully reevaluated in these instances where sequences from the same species differ so significantly. This confusion with species and genus designations rendered it nearly impossible to make assertions about the levels of sequence divergence expected among species within a genus for this phylum. Although only 2 polymorphic sites were found among the QPX A-Y fragment sequences, a single nucleotide difference was also observed between the U. profunda2 and $U$. radiata sequences and between the Labyrinthula yorkensis and Labyrinthuloides minuta2 sequences in this same region of the gene. Phylogenetic analyses based on DNA sequence data for other genes may help resolve the inconsistencies between taxonomies suggested by the current SSU rDNA and morphological data. In addition, in order to determine if different presentations of so-called QPX disease are due to different strains or species of the pathogen, it will be necessary to obtain more sequence data for different geographic isolates and to examine other more variable regions of the QPX genome. The conserved nature of SSU rDNA renders it inappropriate for identification of strain differences; however, sequences not under structural constraint, such as the internal transcribed spacer (ITS) regions, can be very useful for such discrimination. Molecular diagnostics targeting the ITS regions recently have been developed to distinguish among species and/or strains of several disease agents, such as Perkinsus (Reece et al. 2001) and Piscirickettsia salmonis (Heath et al. 2000) and these regions also may be useful for QPX discrimination.
Acknowledgements. The authors thank Dr. Roxanna Smolowitz, Marine Biological Laboratory, Woods Hole, Massachusetts, USA, Dr. Sharon McGladdery, Gulf Fisheries Centre, Moncton, New Brunswick, Canada, and Mr. Bob Barber, Rutgers University, Port Norris, New Jersey, USA, for QPX samples, Rita Crockett and Juanita Walker for preparation of histological sections for ISH, and Karen Hudson and Kathleen Apakupakul for technical assistance with PCR and sequencing. This research was funded by Sea Grant College Program, grant R/A-31. This is VIMS contribution number 2454.

\section{LITERATURE CITED}

Adlard RD, Lester RJG (1995) Development of a diagnostic test for Mikrocytos roughleyi, the aetiological agent of Australian winter mortality of the commercial rock oyster, Saccostrea commercialis (Iredale \& Roughley). J Fish Dis 18:609-614

Altschul SF, Madden TL, Schaffer AA, Zhang J, Zhang Z, Miller W, Lipman DJ (1997) Gapped BLAST and PSIBLAST: a new generation of protein database search programs. Nucleic Acids Res 25:3389-3402

Anderson TJ, Adlard RD, Lester RJG (1995) Molecular diagnosis of Marteilia sydneyi (Paramyxea) in Sydney rock oysters, Saccostrea commercialis (Angas). J Fish Dis 18: 507-510

Berthe FCJ, Le Roux F, Peyretaillade E, Peyret P, Rodriguez D, Gouy M, Vivarès CP (2000) Phylogenetic analysis of the small subunit ribosomal RNA of Marteilia refringens validates the existence of phylum Paramyxea (Desportes and Perkins, 1990). J Eukaryot Microbiol 47:288-293

Bower SM (1987) Labyrinthuloides haliotidis n.sp. (Protozoa: Labyrinthomorpha), a pathogenic parasite of small juvenile abalone in a British Columbia mariculture facility. Can J Zool 65:1996-2007

Carnegie RB, Barber BJ, Culloty SC, Figueras AJ, Distel DL (2000) Development of a PCR assay for detection of the oyster pathogen Bonamia ostreae and support for its inclusion in the Haplosporidia. Dis Aquat Org 42:199-206

Cochennec N, Le Roux F, Berthe F, Gerard A (2000) Detection of Bonamia ostreae based on small subunit ribosomal probe. J Invertebr Pathol 76:26-32.

Day JM, Franklin DE, Brown BL (2000) Use of competitive PCR to detect and quantify Haplosporidium nelsoni infection (MSX disease) in the eastern oyster (Crassostrea virginica). Mar Biotechnol 2:456-465

Drinnan RE, Henderson EB (1963) 1962 mortalities and a possible disease organism in Nequac quahaugs. Annual Report B11. Biological Station, St. Andrews, New Brunswick

Fong D, Chan MMY, Rodriguez D, Chen CC, Liang Y, Littlewood DTJ, Ford SE (1993) Small subunit ribosomal RNA gene sequence of the parasitic protozoan Haplosporidium nelsoni provides a molecular probe for the oyster MSX disease. Mol Biochem Parasitol 62:139-143

Ford SE, Smolowitz R, Ragone Calvo LM, Barber RD, Kraueter JN (1997) Evidence that QPX (Quahog Parasite Unknown) is not present in hatchery-produced hard clam seed. J Shellfish Res 16:519-521

Heath S, Pak S, Marshall S, Prager EM, Orrego C (2000) Monitoring Piscirickettsia salmonis by denaturant gel electrophoresis and competitive PCR. Dis Aquat Org 41:19-29

Hiney MP, Smith PR (1998) Validation of polymerase chain reaction-based techniques for proxy detection of bacterial fish pathogens: framework, problems, and possible solutions for environmental applications. Aquaculture 162:41-68 
Honda D, Yokochi T, Nakahara T, Raghukumar S, Nakagiri A, Schaumann K, Higashihara T (1999) Molecular phylogeny of labyrinthulids and thraustochytrids based on the sequencing of $18 \mathrm{~S}$ ribosomal RNA gene. J Eukaryot Microbiol 46:637-647

Jones GM, O'Dor RK (1983) Ultrastructural observations on a Thraustochytrid fungus parasitic in the gills of squid (Ilex illecebrosus Lesueur). J Parasitol 69:903-911

Kleeman SN, Adlard RD (2000) Molecular detection of Marteilia sydneyi, pathogen of Sydney rock oysters. Dis Aquat Org 40:137-146

Kleinschuster SJ, Smolowitz R, Parent J (1998) In vitro life cycle and propagation of Quahog Parasite Unknown. J Shellfish Res 17(1):75-78

Ko YT, Ford SE, Fong D (1995) Characterization of the small subunit ribosomal RNA gene of the oyster parasite Haplosporidium costale. Mol Marine Biol Biotechnol 4: 236-240

Ko YT, Chan MMY, Ford SE, Fong D (1999) A PCR-ELISA method for direct detection of the oyster pathogen Haplosporidium nelsoni. Mar Biotechnol 1:147-154

Kotob SI, McLaughlin SM, van Berkum P, Faisal M (1999) Discrimination between two Perkinsus spp. isolated from the softshell clam, Mya arenaria, by sequence analysis of two internal transcribed spacer regions and the 5.8S ribosomal RNA gene. Parasitol 119:363-368

Le Roux F, Audemard C, Barnaud A, Berthe F (1999) DNA probes as potential tools for the detection of Marteilia refringens. Mar Biotechnol 1:588-597

Le Roux F, Lornezo G, Peyret P, Audemard C, Figueras A, Vivarès C, Gouy M, Berthe F (2001) Molecular evidence for the existence of two species of Marteilia in Europe. J Eukaryot Microbiol 48:449-454

Maas PAY, Kleinschuster SJ, Dykstra MJ, Smolowitz R, Parent J (1999) Molecular characterization of QPX (Quahog Parasite Unknown), a pathogen of Mercenaria mercenaria. J Shellfish Res 18(2):561-567

MacCallum GS, McGladdery SE (2000) Quahog Parasite Unknown (QPX) in the northern quahog Mercenaria mercenaria (Linnaeus, 1758) and M. mercenaria var. notata from Atlantic Canada, survey results from three maritime provinces. J Shellfish Res 19:43-50

Marsh AG, Gauthier JD, Vasta GR (1995) A semiquantitative PCR assay for assessing Perkinsus marinus infections in the eastern oyster, Crassostrea virginica. J Parasitol 81: $577-583$

McLean N, Porter D (1982) The yellow-spot disease of Tritonia diomedea Bergh, 1894 (Mollusca: Gastropoda: Nudibranchia): encapsulation of the Thraustochytriaceous parasite by host amoebocyte. J Parasitol 68:243-252

Medlin L, Elwood HJ, Stickel S, Sogin ML (1988) The characterization of enzymatically amplified eukaryotic 16S-like rRNA-coding regions. Gene 71:491-499

Murphy NE, Goggin CL (2000) Genetic discrimination of sacculinid parasites (Cirripedia, Rhizocephala): implication for control of introduced green crabs (Carcinus maenas). J Crustac Biol 20:153-157

Porter D (1989) Phylum Labyrinthulomycota. In: Margulis L, Corliss JO, Melkonian M, Chapman DJ (eds) Handbook of Protoctista. Jones and Bartlett Publishers, Boston, p 388-397

Ragan MA, MacCallum GS, Murphy CA, Cannone JJ, Gutell

Editorial responsibility: Albert Sparks,

Seattle, Washington, USA
RR, McGladdery SE (2000) Protistan parasite QPX of hardshell clam Mercenaria mercenaria is a member of Labyrinthulomycota. Dis Aquat Org 42:185-190

Ragone Calvo LM, Walker JG, Burreson EM (1998) Prevalence and distribution of QPX, Quahog Parasite Unknown, in hard clams Mercenaria mercenaria in Virginia, USA. Dis Aquat Org 33:209-219

Reece KS, Siddall ME, Burreson EM, Graves JE (1997) Phylogenetic analysis of Perkinsus based on actin gene sequences. J Parasitol 83:417-423

Reece KS, Brown GD, Hudson KL, Apakupakul K (2001) Inter- and intra-specific genetic variation among Perkinsus species: implications for species identification and development of molecular diagnostics. J Shellfish Res 20: 554

Smolowitz R, Leavitt D, Perkins F (1998) Observations of a protistan disease similar to QPX in Mercenaria mercenaria (hard clams) from the coast of Massachusetts. J Invertebr Pathol 71:9-25

Stokes NA, Burreson EM (1995) A sensitive and specific DNA probe for the oyster pathogen Haplosporidium nelsoni. J Eukaryot Microbiol 42(4):350-357

Stokes NA, Burreson EM (2001) Differential diagnosis of mixed Haplosporidium costale and Haplosporidium nelsoni infections in the eastern oyster, Crassostrea virginica, using DNA probes. J Shellfish Res 20:207-213

Stokes NA, Siddall ME, Burreson EM (1995a) Detection of Haplosporidium nelsoni (Haplosporidia: Haplosporidiidae) in oysters by PCR amplification. Dis Aquat Org 23: $145-152$

Stokes NA, Siddall ME, Burreson EM (1995b) Small subunit ribosomal RNA gene sequence of Minchinia teredinis (Haplosporidia: Haplosporidiidae) and a specific DNA probe and PCR primers for its detection. J Invertebr Pathol 65:300-308

Stokes NA, Walker JG, Burreson EM (1996) Comparison of Haplosporidium nelsoni diagnostic techniques: polymerase chain reaction outperforms histology. J Shellfish Res 15:498

Swofford DL (2001) PAUP*. Phylogenetic analysis using parsimony (*and other methods). Version 4. Sinauer Associates, Sunderland

Thompson JD, Higgins DG, Gibson TJ (1994) Improving the sensitivity of progressive multiple sequence alignment through sequence weighting, positions-specific gap penalties and weight matrix choice. Nucleic Acids Res 22: $4673-4680$

Trembleau A, Bloom FE (1995) Enhanced sensitivity for light and electron microscopic in situ hybridization with multiple simultaneous non-radioactive oligodeoxynucleotide probes. J Histochem Cytochem 43:829-841

Vachot AM, Monnerot M (1996) Extraction, amplification and sequencing of DNA from formaldehyde-fixed specimens. Ancient Biomolecules 1:3-16

Whyte SK, Cawthorn RJ, McGladdery SE (1994) QPX (Quahaug Parasite X), a pathogen of northern quahaug Mercenaria mercenaria from the Gulf of St. Lawrence, Canada. Dis Aquat Org 19:129-136

Yarnall HA, Reece KS, Stokes NA, Burreson EM (2000) A quantitative competitive polymerase chain reaction assay for the oyster pathogen Perkinsus marinus. J Parasitol 86(4):827-837

Submitted: November 17, 2001; Accepted: May 28, 2002

Proofs received from author(s): December 2, 2002 